\title{
Potter Cove, west Antarctic Peninsula, shallow water meiofauna: a seasonal snapshot
}

\author{
F. PASOTTII ${ }^{1}$, P. CONVEY ${ }^{2,3}$ and A. VANREUSEL ${ }^{1}$ \\ ${ }^{1}$ Ghent University, Marine Biology Research Group, Krijgslaan 281/S8, 9000 Ghent, Belgium \\ ${ }^{2}$ British Antarctic Survey, NERC, High Cross, Madingley Road, Cambridge CB3 OET, UK \\ ${ }^{3}$ Gateway Antarctica, University of Canterbury, Private Bag 4800, Christchurch 8140, New Zealand \\ Francesca.pasotti@ugent.be
}

\begin{abstract}
The meiobenthic community of Potter Cove (King George Island, west Antarctic Peninsula) was investigated, focusing on responses to summer/winter conditions in two study sites contrasting in terms of organic matter inputs. Meiofaunal densities were found to be higher in summer and lower in winter, although this result was not significantly related to the in situ availability of organic matter in each season. The combination of food quality and competition for food amongst higher trophic levels may have played a role in determining the standing stocks at the two sites. Meiobenthic winter abundances were sufficiently high to infer that energy sources were not limiting during winter, supporting observations from other studies for both shallow water and continental shelf Antarctic ecosystems. Recruitment within meiofaunal communities was coupled to the seasonal input of fresh detritus for harpacticoid copepods but not for nematodes, suggesting that species-specific life history or trophic features form an important element of the responses observed.
\end{abstract}

Received 20 August 2013, accepted 20 February 2014, first published online 9 May 2014

Key words: benthos, King George Island, larval recruitment, seasonality, standing stocks

\section{Introduction}

The Antarctic marine ecosystem, with its cool water temperatures and strong seasonal fluctuations, represents a unique environment. During the summer, light is available to primary producers, such as microalgae (phytoplankton, sea-ice algae and microphytobenthos) and macroalgae, which are responsible for fixing much of the carbon utilized by marine organisms (Thomas et al. 2008). Despite the seasonality, one of the early paradigms that the Antarctic sessile benthos subsists trophically on the strong seasonal input of phytoplankton blooms and ceases feeding during the remainder of the year' has been subject to subsequent challenge and re-evaluation (e.g. Clarke 1988, Arntz \& Gili 2001). Several recent studies carried out both on the deeper continental shelf and in shallow water coastal sediments (Bowden 2005, Echeverría \& Paiva 2006, Smith et al. 2012) have demonstrated no cessation in feeding in winter and the presence of a 'food bank'. This, coupled with the previously unrecognized capacity of at least some organisms to feed on different elements of the plankton (e. g. protists, nano- and picoplankton via detritus resuspension), allows constant macrobenthic standing stock and community composition, and possibly even year-round recruitment (Arntz \& Gili 2001).

Most research in this field to date has focused on the benthic macrofauna, and the meiofauna has been poorly investigated despite its importance for organic matter remineralization and nutrient cycling, and its role as food for higher trophic levels. Until now only Vanhove et al. (2000), in a study carried out at Signy Island (South Orkney Islands), have addressed the possible relationship between meiofaunal standing stock and primary production, based on fortnightly sampling over one year in a shallow site. Other studies have linked shallow Antarctic meiofaunal taxa abundances and distribution to sediment grain size and/or spatial variation in organic matter input (de Skowronski \& Corbisier 2002, VeitKöhler et al. 2008, Hong et al. 2011). Pasotti et al. (2012) performed laboratory tracer experiments to compare the importance of bacteria versus microalgae for a number of Antarctic meiofaunal taxa. Their results showed that different meiobenthic groups had different feeding capacities for the two labelled food sources used. However, the overall carbon uptake was too low to provide their putative metabolic requirements, leading to the conclusion that other food sources were relevant for these meiobenthic metazoans. Tightly linked to the sediment they inhabit, most meiofauna lack pelagic larvae (Palmer 1988) and it is probable, therefore, that recruitment will be linked to food availability and local biogeochemical conditions.

The present study focused on advancing understanding of the seasonal differences in Antarctic meiofauna by comparing two adjacent shallow water sites contrasting in terms of sediment characteristics, food availability in winter, food availability in summer, and the location and surroundings. The study addressed the hypotheses 


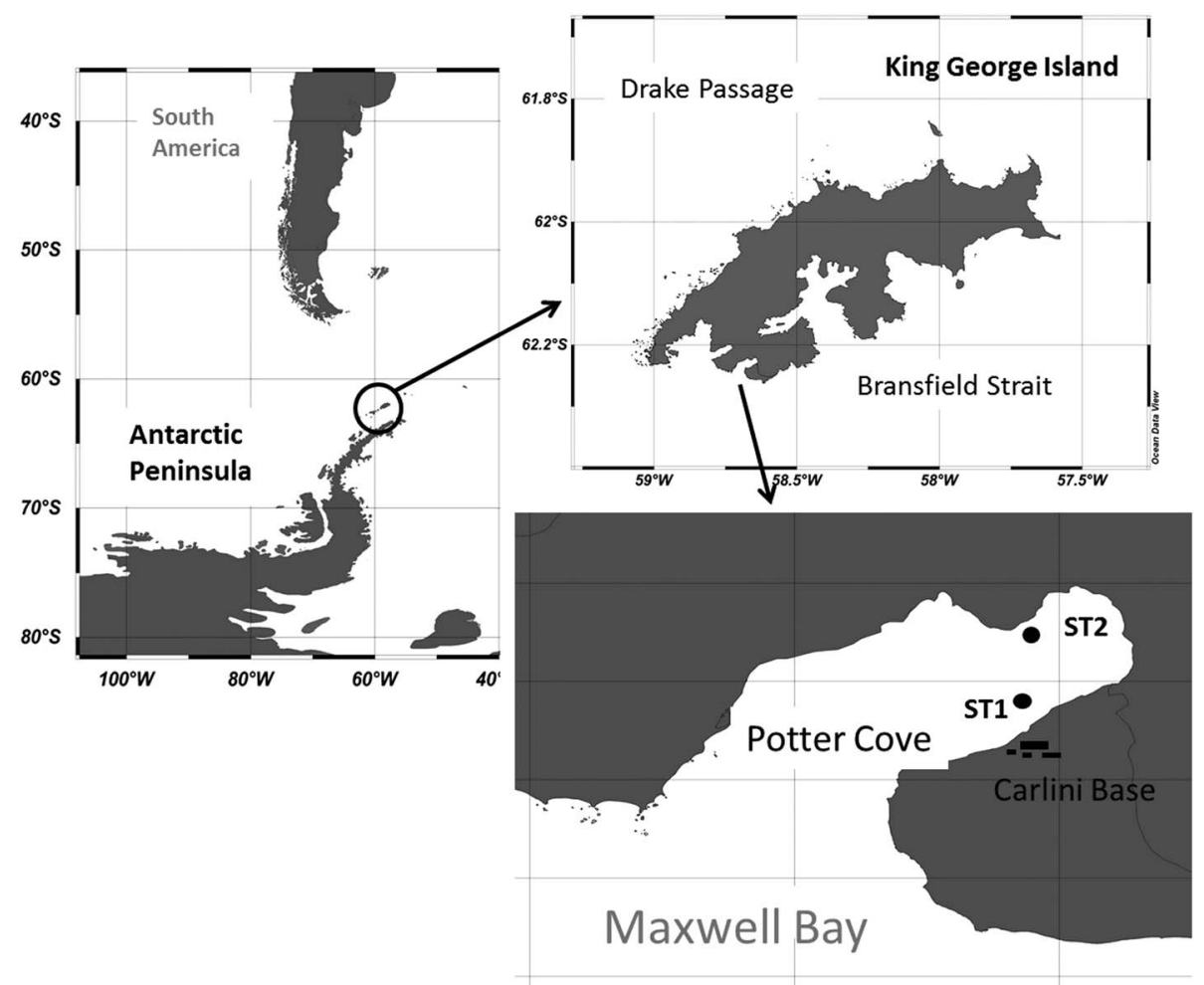

Fig. 1. Map of the location of King George Island and Potter Cove, showing the two study sites (ST1, ST2). that: i) meiofaunal density and nematode biomass are higher in summer compared to winter due to the greater availability of freshly-produced organic material, ii) the main meiofaunal taxa (copepods, nematodes) recruit during the summer season, and iii) the most abundant taxa show similar responses in terms of abundance, biomass and juvenile to adult ratio.

\section{Material and methods}

\section{Study sites and sampling strategy}

Two sites were selected in Potter Cove, a fjord-like embayment on the southern coast of King George Island (Isla 25 de Mayo, South Shetland Islands) situated to the north-west of the Antarctic Peninsula (Fig. 1). The bay is characterized by the presence of a retreating glacier and relatively shallow depths, with a maximum depth of c. $50 \mathrm{~m}$. A clockwise circulation brings sediment-free waters from Maxwell Bay into the cove (Klöser et al. 1994, Schloss et al. 2002). The study sites were two shallow water (15 m depth) stations, located on opposing shores of the cove (Fig. 1). Station 1 (ST1) was adjacent to the Potter Peninsula $\left(62^{\circ} 14^{\prime} 07.2^{\prime \prime} \mathrm{S}, 58^{\circ} 39^{\prime} 56.2^{\prime \prime} \mathrm{W}\right)$, a few hundred metres from the outflow of Potter Creek, a river that flows during the summer months and carries high loads of land-derived material. Station 2 (ST2) was on the north shore, adjacent to the Barton Peninsula, where it is mainly influenced by the clear waters entering the cove.
In late November 2009 (early summer samples) and mid-August 2010 (winter samples), sediment samples were taken at the two sites by scuba diving using Perspex push cores $\left(5.4 \mathrm{~cm}\right.$ inner diameter, $22.89 \mathrm{~cm}^{2}$ surface area, $10-14 \mathrm{~cm}$ sediment depth). At each station and sampling occasion six replicate sediment cores were obtained: three for meiofaunal community analyses, and three for pigment and grain size analyses. The top $2 \mathrm{~cm}$ were carefully cut from the core. For meiofaunal community analysis these were stored in formaldehyde (4\%, buffered with seawater), whilst for pigment and grain size analyses the samples were kept frozen $\left(-20^{\circ} \mathrm{C}\right)$ in the dark until processing. The $0-2 \mathrm{~cm}$ layer was selected since previous studies in Potter Cove have confirmed that it contains the majority of taxa (e.g. the $2-5 \mathrm{~cm}$ layer contains virtually only nematodes and polychaetes) and contributes more than $50 \%$ of the total meiofauna community of the 0-5 cm layer (Pasotti et al. 2012).

\section{Environmental variables}

Grain size analysis was carried out on the three replicates using a Malvern Mastersizer 2000 analyser, after sieving the coarse fraction (boulders, pebbles) on a $1000 \mathrm{~mm}$ screen. Sediment fractions from $0.4-900 \mathrm{~mm}$ were expressed as volume percentages and classified according to the Wentworth (1922) system. After testing for significant differences with PERMANOVA and running a draftsman plot on the detailed size classes $(<4 \mu \mathrm{m}$, 
4-63 $\mu \mathrm{m}, 63-125 \mu \mathrm{m}, 125-250 \mu \mathrm{m}, 250-500 \mu \mathrm{m},>500 \mu \mathrm{m}$; data not shown), considerable redundancy was identified between the various sediment size classes. In light of the high redundancy of the various sediment size classes, and in order to generate a readable output from the principal component analysis (PCA) carried out on the complete set of environmental variables, sediment size was grouped into two classes, namely silt $(0.4-63 \mu \mathrm{m})$ and sand $(63-1600 \mu \mathrm{m})$. For this reason the results only include these two size classes.

Total nitrogen (TN), total organic carbon (TOC), total carbon (non-acidified samples) to nitrogen ratio $(\mathrm{C} / \mathrm{N})$ and organic carbon (acidified samples) to nitrogen ratio $\left(\mathrm{C}_{\text {org }} / \mathrm{N}\right)$ were determined on triplicate, dried and, when needed, acidified (with $10 \mathrm{~N} \mathrm{HCl}$ ) sediment samples using a Flash 2000 organic element analyser.

Pigment concentration analysis was carried out on three replicates obtained at each site and sampling occasion. The sediment was first lyophilized and homogenized, then extracted in $90 \%$ acetone and separated using reversephase high-performance liquid chromatography. The resulting solution was subjected to spectrophotometric analysis with a fluorescence detector (Gilson Inc, model number 121) in order to estimate the pigment concentration (Jeffrey et al. 1997). Chloroplast Pigment Equivalents (CPE, $\mu \mathrm{g} \mathrm{C} \mathrm{g}^{-1}$ dry sediment) were derived as the sum of chlorophyll $a$ (chl $a$ ) and its degradation products (phaeopigments). Fucoxanthin concentration ( $\mu \mathrm{g} \mathrm{Cg} \mathrm{g}^{-1}$ dry sediment) was used as an indicator of brown/golden brown algae presence (Dring 1982).

\section{Meiofaunal abundance and biomass}

The extraction of meiofauna followed standard procedures of centrifugation-rotation with LUDOX HS40, and sieving over 1000 and $32 \mu \mathrm{m}$ sieves (Heip et al. 1985, Vincx 1996). Counting was carried out following sub-replication with a meiofauna sample splitter (Jensen 1982) for the more numerous taxa (nematodes, copepods and nauplii), with total counts being completed for other taxa. From the sample splitter, which contains eight chambers, three were randomly selected to be used as sub-replicates of the sample for counting nematodes, copepods and nauplii.

Nematodes were identified at the genus level, collecting c. 100 individuals randomly from each replicate and mounting them on glass slides. The online key for freeliving marine nematodes (NeMysKey ${ }^{\mathcal{C}}$ ) and the key from Warwick et al. (1998) were used for identification. Nematode trophic guild composition was described based on the definitions given by Wieser (1953). Standard methods were used for nematode (c. 1200

Table I. Results for PERMANOVA analysis of biological and environmental data from ST1 and ST2 during summer and winter.

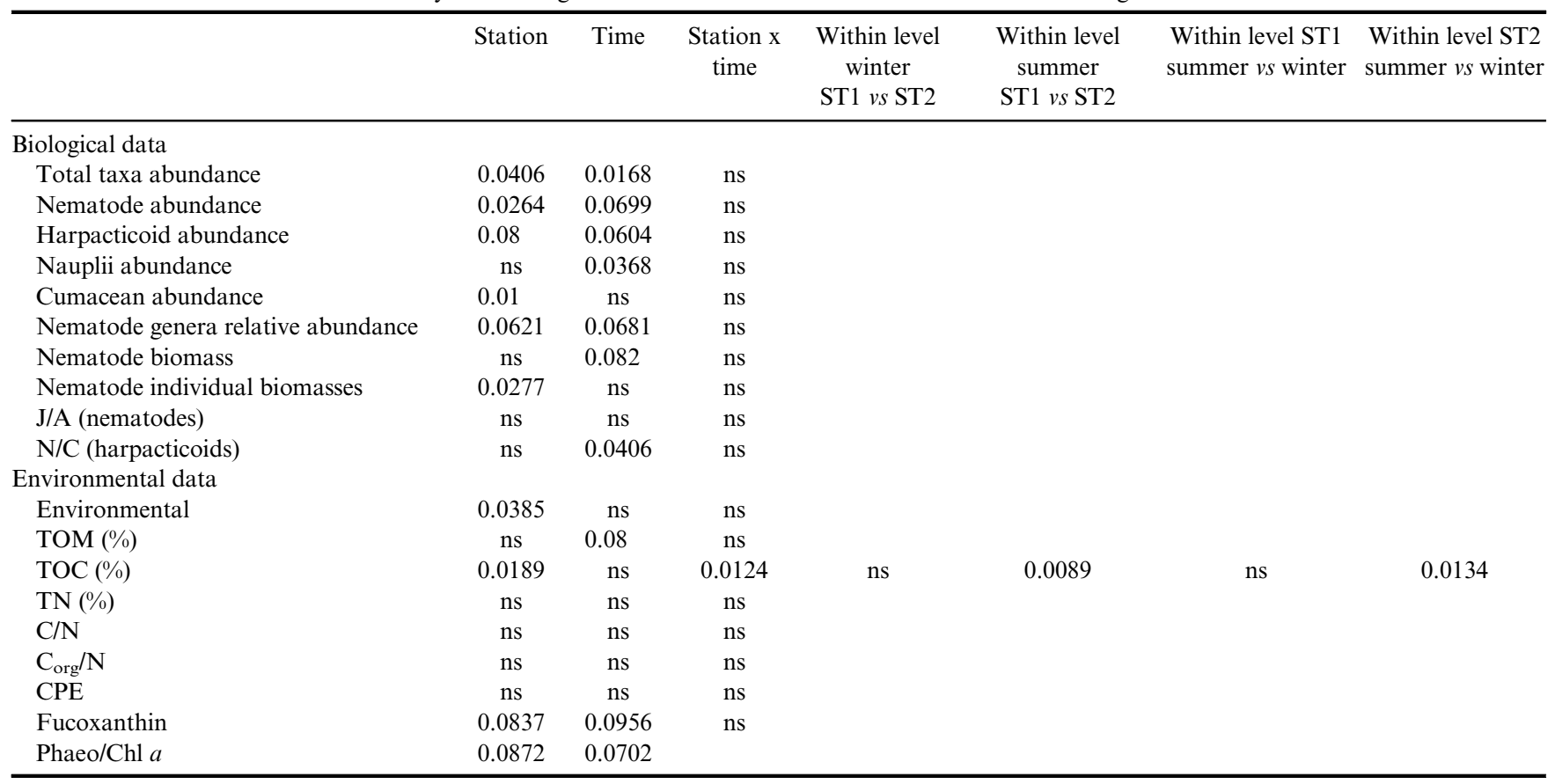

ns $=P \geq 0.1$.

$\mathrm{C} / \mathrm{N}=$ total carbon (non-acidified samples) to nitrogen ratio, $\mathrm{C}_{\mathrm{org}} / \mathrm{N}=$ organic carbon (acidified samples) to nitrogen ratio, $\mathrm{CPE}=$ chloroplast pigment equivalents, $\mathrm{J} / \mathrm{A}=$ juveniles to adults ratio in nematodes, N/C = nauplii to copepodids ratio in harpacticoids, phaeo/Chl $a=$ phaeopigments to chlorophyll $a$ ratio, $\mathrm{TN}=$ total nitrogen, $\mathrm{TOC}=$ total organic carbon, $\mathrm{TOM}=$ total organic matter. 


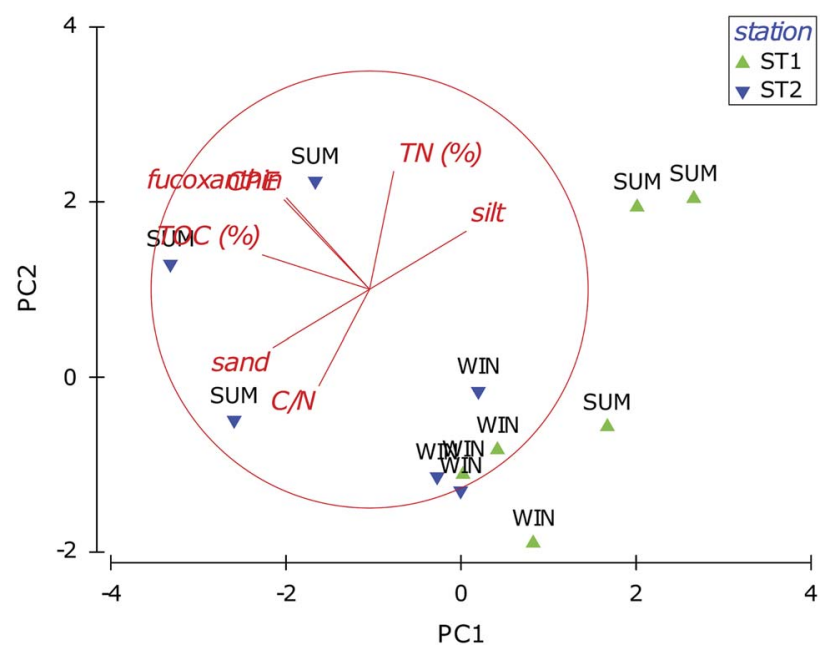

Fig. 2. Principal component analysis (PCA) based on the environmental parameters chloroplast pigment equivalents $(\mathrm{CPE})$, carbon to nitrogen ratio $(\mathrm{C} / \mathrm{N})$, fucoxanthin concentration, total organic carbon concentration (TOC, \%), total nitrogen (TN, \%), sand (\%) and silt ( $\%$ ). $\mathrm{SUM}=$ summer, WIN $=$ winter.

nematodes per replicate) biomass determination, based on estimation of body volume using Andrássy's formula (Andrássy 1956):

$$
\mathrm{V}=\mathrm{L} \times \mathrm{W}^{2} / 16 \times 10^{5}
$$

where $\mathrm{V}$ is the volume in nanolitres, $\mathrm{L}$ is the length in $\mu \mathrm{m}$ (excluding filiform tails, if present) and $\mathrm{W}$ is maximum width in $\mu \mathrm{m}$. Body volume was converted to biomass ( $\mu \mathrm{g}$ wet weight $10 \mathrm{~cm}^{-2}$ ) assuming a specific gravity of 1.13 (Wieser 1960) and a dry/wet weight (DW/WW) ratio of 0.25 . Individual biomass was then converted to carbon assuming a $\mathrm{DW} \mu \mathrm{g}^{-1} \mathrm{C}$ ratio of 0.124 (Jensen 1984). Community biomass values $\left(\mu \mathrm{g} \mathrm{C} 10 \mathrm{~cm}^{-2}\right.$ ) were calculated as the product of nematode densities (individuals per $10 \mathrm{~cm}^{2}$ ) and the arithmetic mean of individual biomass values.

As a tool for the investigation of seasonality in recruitment dynamics, juvenile to adult ratio (J/A) was calculated for nematodes and expressed as the ratio of juveniles versus female and male adults. For harpacticoid copepods, the nauplii to copepodids ratio (N/C) was calculated, where copepodids included copepodid I-V (juvenile forms) and copepodid VI or adult forms.

\section{Statistical analysis}

To test for differences between stations and seasons in meiofaunal densities and biomass (all fauna combined, and nematodes, harpacticoid copepods, cumaceans and nauplii separately), nematode genera, and environmental variables non-parametric permutational ANOVAs (PERMANOVA) with a fully crossed three-factor design were performed with random factor core 'co' nested in the fixed factor station 'st', next to the fixed factor time 'ti'. The interaction term 'st $\mathrm{x}$ ti' gives information about the differences at each time of the above-mentioned parameters between the stations.

A Euclidean distance-based resemblance matrix was used for the analysis of the environmental variables, while a Bray-Curtis similarity resemblance matrix was used for the abundance and biomass data. In cases of significant 'st $x$ ti' interactions, pairwise tests of 'st' and ' $t$ ' within 'st $x$ ti' were performed to investigate in which period (summer or winter) the stations differed. Due to the restricted number of possible permutations in pairwise tests, p-values were obtained from Monte Carlo sampling (Anderson \& Robinson 2003). PERMDISP analysis was not used since it is not appropriate for small sample sizes where $n<5$ (Anderson et al. 2008).

For the nematode genera composition, multidimensional scaling (MDS) was performed in order to better visualize the results. Two-way crossed analysis of similarity (ANOSIM) was performed in order to test for differences between stations or times. A PCA was run to represent the influence of the environmental variables at the different sampling stations. Abundance and biomass data were fourth root transformed prior to the analysis of the whole community, while nematode genus relative abundances were square root transformed. Environmental data were normalized since variables with different unit measures were analysed together.

\section{Results}

A summary of all PERMANOVA results is provided in Table I.

\section{Environmental description}

The PERMANOVA generated a significant p-value for the factor 'st', indicating that the two sampling stations

Table II. Sedimentary organic matter composition.

\begin{tabular}{llccrr}
\hline & & TOM $(\%)$ & TN $(\%)$ & TOC $(\%)$ & C/N \\
\hline Summer & ST1 & $5.22 \pm 0.94$ & $0.09 \pm 0.05$ & $0.29 \pm 0.007$ & $10.4 \pm 11.35$ \\
\multirow{3}{*}{ Winter } & ST2 & $6.09 \pm 0.73$ & $0.067 \pm 0.01$ & $0.69 \pm 0.06$ & $19.13 \pm 2.71$ \\
& ST1 & $3.88 \pm 0.38$ & $0.03 \pm 0.01$ & $0.35 \pm 0.11$ & $20.71 \pm 5.53$ \\
& ST2 & $3.87 \pm 1.06$ & $0.03 \pm 0.006$ & $0.45 \pm 0.10$ & $15.22 \pm 2.19$ \\
\hline
\end{tabular}

$\mathrm{C} / \mathrm{N}=$ total carbon (non-acidified samples) to nitrogen ratio, $\mathrm{C}_{\mathrm{org}} / \mathrm{N}=$ organic carbon (acidified samples) to nitrogen ratio, $\mathrm{TN}=$ total nitrogen, $\mathrm{TOC}=$ total organic carbon, $\mathrm{TOM}=$ total organic matter. 
differed in terms of environmental variables. There were no significant differences between the summer and winter sampling periods. The PCA indicated that the two stations differed mainly in TOC and CPE content during summer, whilst in winter there were no clear differences (Fig. 2).

\section{Grain size}

The PERMANOVA run on the silt and sand classes showed that neither 'st' $(P=0.0699)$ nor 'ti' $(P>0.1)$ were significantly different.

\section{Sedimentary organic matter}

Mean values for total organic material (TOM, \%), TOC $(\%), \mathrm{TN}(\%), \mathrm{C} / \mathrm{N}$ and $\mathrm{C}_{\text {org }} / \mathrm{N}$ are reported in Table II. Only TOC was significant at $P<0.05$ (see Table I) for the 'st $\mathrm{x}$ ti' factor. Analysis of TOM identified only a minor and non-significant influence of time, with PERMANOVA results giving a p-value of 0.08 . The TN and $\mathrm{C} / \mathrm{N}$ did not differ between either stations or seasons. Percentages of TOC varied significantly for 'st $\mathrm{x}$ ti' $(P=0.012)$, with higher values at ST2 $(0.69 \pm 0.06)$ compared to ST1 $(0.29 \pm 0.007)$ in summer (pairwise test $P=0.0089$ ). At ST1, the TOC did not vary significantly between seasons whilst it was significantly higher in summer compared to winter in ST2 (pairwise test $P=0.013)$. Percentages of TOM showed a decrease at both stations from summer (ST1 $5.22 \pm 0.94$, ST2 $6.09 \pm 0.73$ ) to winter (ST1 $3.88 \pm 0.38$, ST2 $3.87 \pm 1.06$ ).

\section{Pigments}

No significant differences in CPE or phaeopigment concentrations between sampling locations or seasons were identified by PERMANOVA. The CPE concentrations

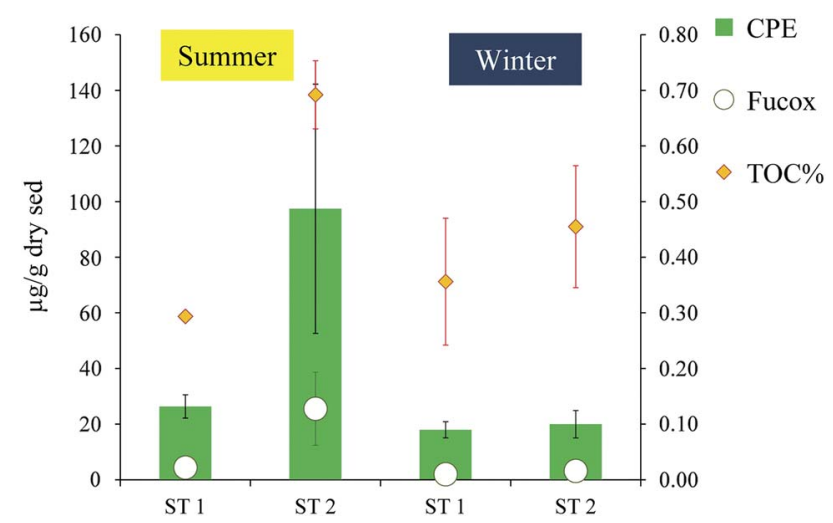

Fig. 3. Chloroplast pigment equivalents (CPE), fucoxanthin concentration ( $\mu \mathrm{g} \mathrm{g}^{-1}$ dry sediment $\pm \mathrm{SD}$, left axis) and total organic carbon (TOC) concentration $(\% \pm \mathrm{SD}$, right axis) at the two sampling stations during summer and winter.

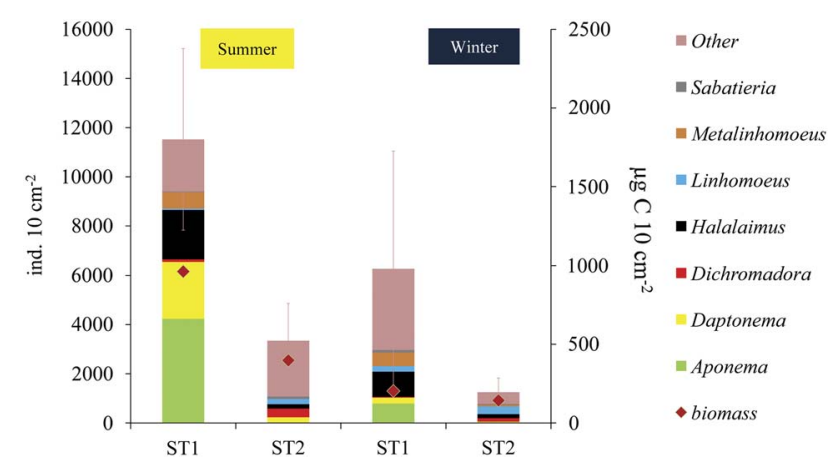

Fig. 4. Nematode densities (vertical bars, ind. $10 \mathrm{~cm}^{-2} \pm \mathrm{SD}$, left axis), nematode biomass (red rhombus, $\mu \mathrm{g} \mathrm{C} 10 \mathrm{~cm}^{-2} \pm \mathrm{SD}$, right axis) and mean relative genus abundance at each study site during summer and winter.

were typically much higher in ST2 than ST1 during summer (Fig. 3), although with large variation (97.44 \pm 44.79 and $26.39 \pm 4.18 \mu \mathrm{g} \mathrm{g}^{-1} \mathrm{DW}$ sediment, respectively). There were no differences between the two sampling stations during winter.

Fucoxanthin concentrations indicated non-significant differences for 'st' $(P=0.08)$ and for 'ti' $(P=0.09)$. The highest concentration was found at ST2 in summer $\left(25.5 \pm 13.1 \mu \mathrm{g} \mathrm{g}^{-1} \mathrm{DW}\right)$.

\section{Meiofaunal abundances}

Total meiofaunal abundances were significant for 'st' and 'ti' (PERMANOVA). The two sampling stations differed from each other only during summer, whilst ST2 showed differences between summer and winter. Higher numbers were present in ST1 compared to ST2 during summer (12 $181 \pm 3821$ and $4681 \pm 1683$ ind. $10 \mathrm{~cm}^{-2}$, respectively). The total abundances at ST2 dropped from $4681 \pm 1683$ ind. $10 \mathrm{~cm}^{-2}$ in summer to $1307 \pm 614$ ind. $10 \mathrm{~cm}^{-2}$ in winter.

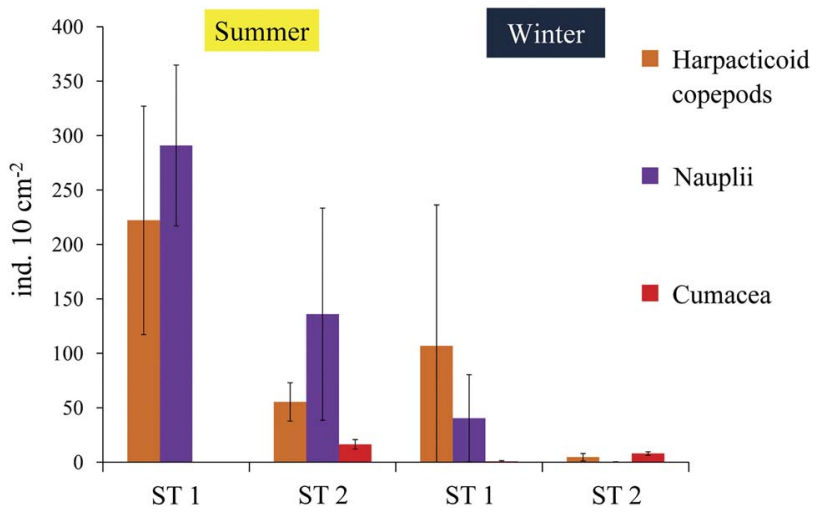

Fig. 5. Harpacticoid copepod, nauplii and cumacean abundances (ind. $10 \mathrm{~cm}^{-2} \pm \mathrm{SD}$ ) at each study site during summer and winter. 


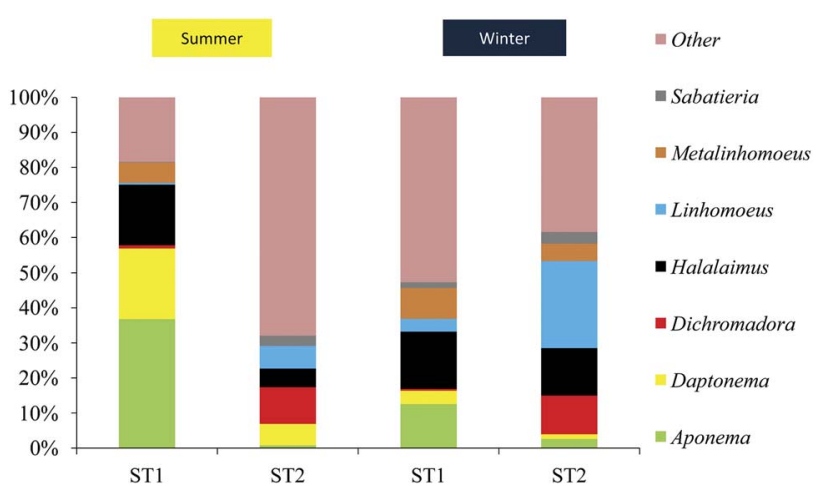

Fig. 6. Relative abundances of the most abundant nematode genera at the two study sites during summer and winter.

Nematodes were always the most abundant and numerically important taxon, constituting $92 \%$ of the community in summer at ST2 and $95 \%$ at ST1, while in winter their relative abundances were $98 \%$ and $97 \%$, respectively. Nematode abundances were around one order of magnitude higher in ST1, with no significant differences between seasons (Fig. 4). At ST2 there was some indication of a seasonal difference, although the PERMANOVA p-value was non-significant $(P=0.069)$. Harpacticoid copepods (Fig. 5) showed higher abundances in summer compared to winter $(P=0.06)$. Nauplii abundance showed a significant seasonal change $(P=0.0368)$, with lower numbers in winter (Fig. 5). Cumaceans were significantly more abundant at ST2, with no seasonal change (Fig. 5).

\section{Nematode genus composition}

The nematode genus composition showed marginally non-significant $\mathrm{p}$-values for both 'st' and 'ti' $(P=0.0621$ and $P=0.0681$, respectively). The nematode community genus composition differed between stations and seasons

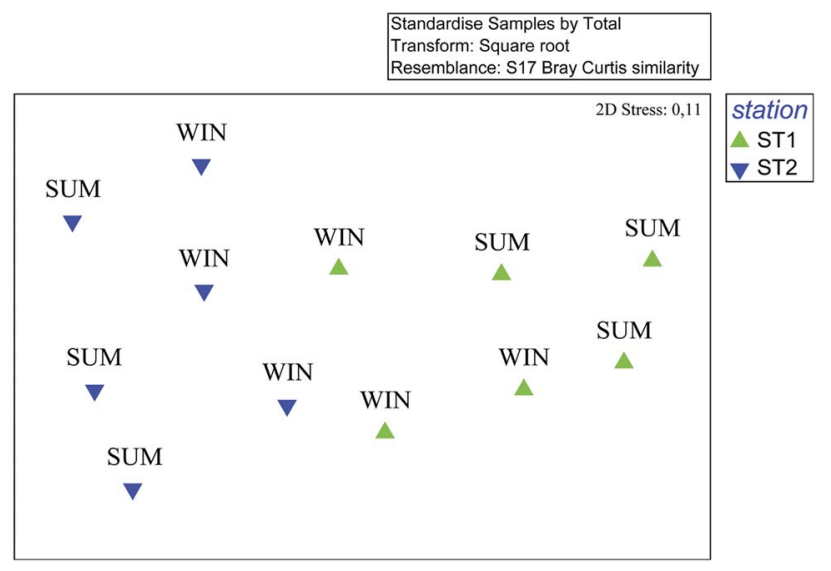

Fig. 7. Multi-dimensional scaling (MDS) results based on nematode genus relative abundances (square root transformed) at the two study sites.

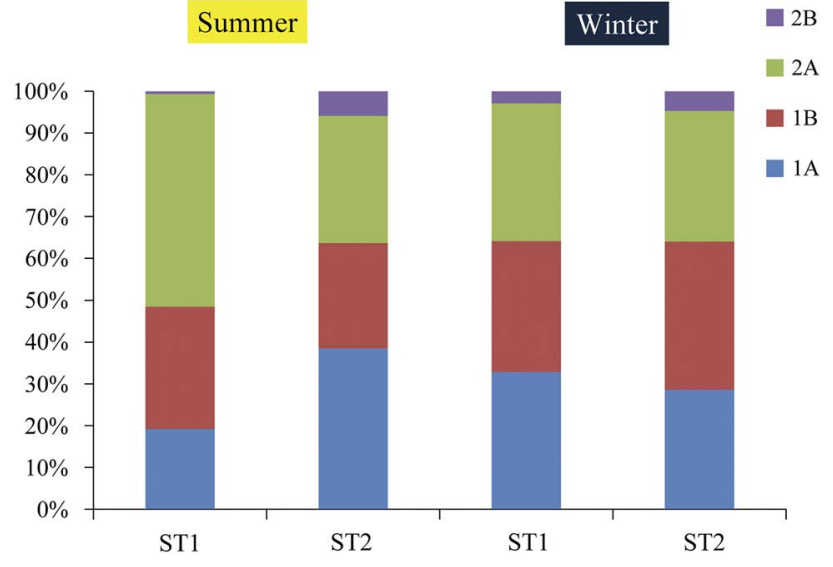

Fig. 8. Trophic composition of the nematode community.

Based on the feeding guilds of Wieser (1953): 1A = selective deposit feeders, $1 \mathrm{~B}=$ non-selective deposit feeders,

$2 \mathrm{~A}=$ epistrate feeders, $2 \mathrm{~B}=$ predators.

(Figs 4 \& 6). The MDS (Fig. 7) based on genus composition indicated that the two stations clearly differed during the summer, whereas winter samples were less distinct (two-way crossed ANOSIM: between stations $R=0.815, P=0.01$, between times $R=0.519$, $P=0.01)$. The ST1 nematode community in summer was dominated by three genera: Aponema $(38 \%)$, Daptonema (21\%) and Halalaimus (15\%). ST2 showed a more even and diverse community, with the highest relative abundance contributed by Dichromadora (18\%). In winter, the ST1 community was still dominated by few genera, with Halalaimus (23\%) followed by Aponema $(20 \%)$ and Metalinhomoeus (12\%), and ST2 was more evenly structured, with Linhomoeus (20\%) followed by Halalaimus (15\%) and Dichromadora (10\%). The relative abundances of the different nematode trophic groups are illustrated in Fig. 8. ST1 in summer appeared to host a higher relative presence of grazing genera, such as the epistrate feeding group (2A), although PERMANOVA did not identify a significant difference. Reflecting the genus composition data, the communities at ST2 during summer and at both stations during winter showed more even trophic composition, with selective deposit feeders $(1 \mathrm{~A}, 38 \%)$ followed by epistrate feeders $(2 \mathrm{~A}, 30 \%)$ and non-selective deposit feeders (1B, 25\%), and a relatively high presence of predators $(2 \mathrm{~B}, c .5 \%)$. In ST1 during summer, there was a relatively greater abundance of epistrate feeders (2A) (up to $60 \%$, average $50 \%$ ) and a very low representation of predators $(2 \mathrm{~B}, 0.6 \%)$.

\section{Nematode biomass}

Nematode biomass $\left(\mu \mathrm{g} \mathrm{C} 10 \mathrm{~cm}^{-2}\right.$ ) data are presented in Fig. 4. The highest biomass values were recorded at ST1 during summer, reaching up to $2.2 \mathrm{mg} \mathrm{C} 10 \mathrm{~cm}^{-2}$, although with very high variability. Biomass generally 


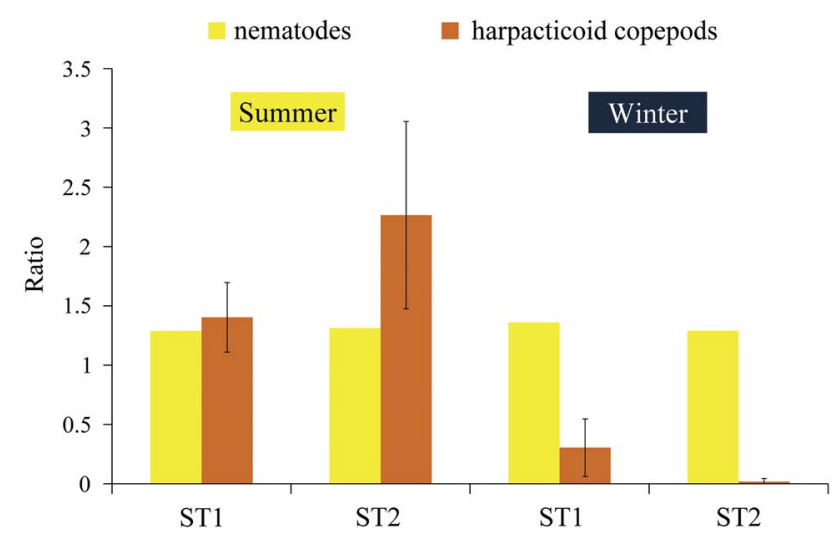

Fig. 9. Ratio of juvenile to adult (J/A) nematodes and nauplii larvae to copepodids I-V and VI (N/C) (mean \pm SD).

decreased from summer to winter, more noticeably at ST1. There was a significant difference in individual biomass between sampling stations $(P=0.0277)$ but not between seasons, with ST2 hosting larger nematodes than ST1 $\left(0.1 \pm 0.04 \mu \mathrm{g} \mathrm{C}\right.$ ind $^{-1}$ in ST2, $0.04 \pm 0.01 \mu \mathrm{g} \mathrm{C}$ ind. ${ }^{-1}$ in ST1). The nematode length to width ratios (L/W) were not significantly different between sampling stations or seasons. The average L/W values ranged between $27 \pm 11$ and $33 \pm 15$ in ST1 and $30 \pm 12$ and $35 \pm 19$ in ST2, in summer and winter, respectively.

\section{Juvenile to adult ratios}

No significant differences were detected between the two sampling stations. There were significant differences $(P=0.04)$ in N/C for harpacticoids between seasons (Fig. 9), with higher values in summer (ST1 $1.40 \pm 0.35$ in summer vs $0.30 \pm 0.29$ in winter, ST2 $2.26 \pm 0.96$ in summer vs $0.01 \pm 0.03$ in winter). Harpacticoids showed the highest ratio during the summer at ST2 (Fig. 9). Nematode J/A did not show any significant differences between sampling stations or seasons, showing a generally constant value of $1.13 \pm 0.34$ (Fig. 9).

\section{Discussion}

\section{Spatial differences}

To clarify the possible effects of seasonality on meiobenthic community structure at the two study sites the environmental similarities and differences are first discussed. Granulometrically similar to one another, the two sites differed mainly in terms of organic matter content. ST2 showed organically richer $(>$ TOC, $>$ CPE concentration, $>$ fucoxanthin concentration) sediments compared to ST1 during summer, whilst in winter the concentrations were more similar, with a general decrease in TOM content. The CPE values found in the sediments of both sites were comparable to those previously reported from Potter Cove (Veit-Köhler 2005) and from the Terra Nova Bay continental shelf (Pusceddu et al. 2000). Percentages of TOC in the current study were remarkably low (never $>0.8 \%$ ), and were lower than those found in Hornsund Fjord (Spitsbergen, Arctic) (Grzelak \& Kotwicki 2012) and in a deep sea canyon (Ingels et al. 2011). Despite these low TOC values, meiofaunal abundances were up to one order of magnitude higher than those in Hornsund Fjord, and biomass showed values comparable to, if not higher than, those found in productive systems such as an estuary (Tita et al. 2002). The higher TOC values at ST2 were not reflected in higher meiofauna densities or biomass.

Overall, the meiofauna showed peaks of abundance ( $>10000$ ind $\mathrm{cm}^{-2}$ ) comparable to previous reports in Potter Cove (Pasotti et al. 2012 and references therein) and Signy Island (South Orkney Islands, Vanhove et al. 2000). These values were much higher than those reported by Hong et al. (2011) in the adjacent Marian Cove (King George Island). Biomass values were high (up to $2 \mathrm{mg} \mathrm{C} 10 \mathrm{~cm}^{-2}$ ), comparable to those found in temperate estuaries (Tietjen 1969), and up to two orders of magnitude higher than those reported for deep sea sites (Gambi et al. 2010). When the two study sites were compared in terms of meiobenthic densities and community composition, they differed only in summer, with higher values and greater diversity in ST1.

Differences in meiobenthos abundances have often been correlated to sediment grain size (de Skowronski \& Corbisier 2002) or organic matter availability (Vanhove et al. 2000). However, here both stations were highly dominated by mud (on average $>80 \%$ ) and no significant differences in sediment composition were detected. When comparing the two sites during summer, it is notable that, despite the higher food availability, the nematode community at ST2 did not achieve higher biomass. Coull (1999), in a review on the role of meiofauna in estuarine systems, argued that food quality rather than quantity was a more important influence on meiofaunal standing stocks. It is plausible that the organic matter present at ST2 was not directly exploitable by the fauna. During the summer months, brown seaweeds, such as perennial Desmarestiales species, are responsible for high primary production in Potter Cove, leading to high macroalgal biomass potentially becoming available as detritus (Quartino \& de Zaixso 2008). Most macroalgal primary production currently takes place on rocky substrata along the outer part of the northern side of the cove, with some recent evidence of colonization of newly ice-free substrata in the inner parts of the cove (Quartino et al. 2013). While macroalgae are generally recognized to be highly unpalatable to many organisms, they still provide a potential carbon source through the activity of microbial decomposition processes. Prokaryotic decomposition of available organic matter results in lowered oxygen concentration in the sediments where these 
biochemical reactions take place. Thus, the overall lower abundance of meiofauna and the lower nematode biomass found at ST2 compared to ST1, combined with the relatively greater presence in summer of the nematode feeding group 1A (selective deposit feeders, 38\%), could provide further support to this hypothesis. Nematodes at both study sites showed very high L/W values, indicating that generally slender nematodes inhabit these sediments, which is assumed to be an adaptation to low oxygen conditions (Jensen 1987).

It appears that summer macroalgal primary production in Potter Cove may not directly stimulate the meiobenthos, and may negatively impact the community by generating sub-oxic and stressful conditions within the sediments. Further studies are required in order to confirm this hypothesis. Local differences in macrofaunal standing stocks could also play an important role in terms of competition with the meiofauna for the available food sources.

\section{Seasonal differences}

Meiofaunal densities varied significantly between summer and winter at ST2. Here average winter densities decreased to half of the summer values. A similar pattern was observed for ST1, although due to high variances this was not statistically significant. Biomass values for both stations showed a significant decline from summer to winter months. Seasonal dissimilarities were driven mainly by differences in the communities of the two main taxa, nematodes and copepods. The reduction in total meiofaunal densities between seasons is a pattern described by Vanhove et al. (2000) in a different Antarctic shallow water environment and by Pawłowska et al. (2011) in the Arctic. From our study, we can postulate that the seasonal decrease in meiobenthos standing stocks in Potter Cove could be due to: i) the more refractory nature of the organic matter in winter, or ii) the possible local decrease in oxygen concentration at the water-sediment interface due to cessation of benthic primary production and the continuation of benthic respiration during the winter months. Nonetheless, the relatively high nematode densities and biomass values that were present during this period suggest that summer primary production had been converted before the winter months into other potential food sources (e.g. prokaryotes, protozoan biomass or detritus). If so, the biomass reduction observed is related to mortality of the meiofauna.

The J/A data obtained in this study shows that copepod larval abundance changed with season, with significantly higher numbers present in summer, whereas no pattern was present for the nematodes (Fig. 9). This contrasts with the findings of a study of sub-Arctic harpacticoid species (Steinarsdóttir et al. 2003), where the copepods brooded all year round, again supporting a constant availability of food. This may indicate species-specific life strategies not investigated in the current study.

The meiofaunal seasonal abundance patterns differed among the taxa studied. Nematodes and copepods showed lower abundance during winter, whilst cumaceans did not show significant seasonal changes. Nematodes are represented by various trophic guilds, some of which are dependent on fresh material such as benthic diatoms, prokaryotes or other metazoans (epistrate feeders, selective deposit feeders and predators). Harpacticoid copepods are known to feed actively on microalgae, biofilms or detritus, and cumaceans to feed mainly on detritus, although certain species can be predators. Pasotti et al. (2012) reported a preference for phytoplanktonic diatom detritus compared to bacterial detritus in Potter Cove cumaceans. The data available suggest different interactions of each metazoan group with its environment, and also differences between summer and winter seasons. Life strategies, trophic and other species-specific characteristics play an important role in determining meiofaunal responses to environmental changes in Antarctic shallow water ecosystems.

\section{Conclusions}

Meiofaunal densities in Potter Cove were generally higher in summer and lower in winter, although seasonal input of organic matter did not seem to underlie this difference. This may be linked with the occurrence of food-qualityrelated sub-oxic conditions.

Winter meiofaunal abundances were sufficiently high to infer that energy sources are not limited during winter. This is consistent with the hypothesis that there is no cessation in feeding, as argued by other authors for both shallow water and shelf Antarctic ecosystems.

Recruitment in meiofaunal communities can be coupled or uncoupled to the seasonal input of fresh detritus, possibly linked to species-specific life history characteristics or to the trophic flexibility of the investigated taxon.

\section{Acknowledgements}

We acknowledge the ESF IMCOAST project (impact of climate induced glacial melting on marine coastal systems in the western Antarctic Peninsula region, www.imcoast. org) for financial support. FP was financed through an IWT PhD scholarship and by Ghent University. PC is supported by NERC core funding to the BAS 'Ecosystems' Programme. We thank the Alfred Wegener Institute and the Instituto Antartico Argentino for providing logistic support at the Dallmann Laboratory in Carlini Station. Special thanks to Prof Dr Doris Abele and Oscar Gonzáles for their assistance and support. We thank all the scientific and support staff at Carlini Station for their assistance in the diving and boating operations necessary for the collection of the material described. We 
would also like to thank the reviewers for their comments on the manuscript.

\section{References}

Anderson, M.J. \& Robinson, J. 2003. Generalized discriminant analysis based on distances. Australian \& New Zealand Journal of Statistics, 45, 301-318.

Anderson, M.J., Gorley, R.N. \& Clarke, K.R. 2008. PERMANOVA + for PRIMER: guide to software and statistical methods. Plymouth: PRIMER-E Ltd.

AndrÁssy, I. 1956. Die Rauminhalts und Gewichtsbestimmung der Fadenwurmer (Nematoden). Acta Zoologica Academiae Scientiarum Hungaricae, 2, 1-15.

ARNTZ, W.E. \& GILI, J.-M. 2001. A case for tolerance in marine ecology: let us not put out the baby with the bathwater. Scientia Marina, 65, 283-299.

Bowden, D.A. 2005. Seasonality of recruitment in Antarctic sessile marine benthos. Marine Ecology Progress Series, 297, 101-118.

Clarke, A. 1988. Seasonality in the Antarctic marine environment. Comparative Biochemistry and Physiology - Biochemistry \& Molecular Biology, 90B, 461-473.

Coull, B.C. 1999. Role of meiofauna in estuarine soft-bottom habitats. Australian Journal of Ecology, 24, 327-343.

DrING, M.J. 1982. The biology of marine plants. London: Edward Arnold, 199 pp.

Echeverría, C.A. \& Paiva, P.C. 2006. Macrofaunal shallow benthic communities along a discontinuous annual cycle at Admiralty Bay, King George Island, Antarctica. Polar Biology, 29, 263-269.

Gambi, C., Lampadariou, N. \& Danovaro, R. 2010. Latitudinal, longitudinal and bathymetric patterns of abundance, biomass of metazoan meiofauna: importance of the rare taxa and anomalies in the deep Mediterranean Sea. Advances in Oceanography and Limnology, 1, 167-197.

Grzelak, K. \& Kotwicki, L. 2012. Meiofaunal distribution in Hornsund fjord, Spitsbergen. Polar Biology, 35, 269-280.

Heip, C., Vincx, M. \& Vranken, G. 1985. The ecology of marine nematodes. Oceanography and Marine Biology, 23, 399-489.

Hong, J.-H., Kim, K., Lee, S., Back, J., Lee, D.J. \& Lee, W. 2011. The community structure of meiofauna in Marian Cove, King George Island, Antarctica. Ocean and Polar Research, 33, 265-280. [Korean].

Ingels, J., Billet, D.S.M., Kiriakoulakis，K., Wolff, G.A. \& VAnreusel, A. 2011. Structural and functional diversity of Nematoda in relation with environmental variables in the Setúbal and Cascais canyons, western Iberian Margin. Deep Sea Research II Topical Studies in Oceanography, 58, 2354-2368.

Jefrrey, S.W., Mantoura, R.F.C. \& Wright, S.W., eds. 1997. Phytoplankton pigments in oceanography: guidelines to modern method. Paris: UNESCO Publishing, 661 pp.

Jensen, P. 1982. A new meiofauna sample splitter. Annales Zoologici Fennici, 19, 233-236.

Jensen, P. 1984. Measuring carbon content in nematodes. Helgoland Meeresuntersuchungen, 38, 83-86.

JENSEN, P. 1987. Differences in microhabitat, abundance, biomass and body size between oxybiotic and thiobiotic free-living marine nematodes. Oecologia, 71, 564-567.

Klöser, H., Ferreyra, G., Schloss, L., Mercuri, G., Laturnus, F. \& Curtosi, A. 1994. Hydrography of Potter Cove, a small fjord-like inlet on King George Island (South Shetland). Estuarine, Coastal and Shelf Science, 38, 523-537.

Pasotti, F., de Troch, M., Raes, M. \& Vanreusel, A. 2012. Feeding ecology of shallow water meiofauna: insights from a stable isotope tracer experiment in Potter Cove, King George Island, Antarctica. Polar Biology, 35, 1629-1640.
Palmer, M.A. 1988. Dispersal of marine meiofauna: a review and conceptual model explaining passive transport and active emergence with implications for recruitment. Marine Ecology Progress Series, 48 , 81-91.

PawŁowsKa, J., WŁodarska-KowalczuK, M., ZajaÇZKowski, M., NygÅrd, H. \& Berge, J. 2011. Seasonal variability of meio- and macrobenthic standing stocks and diversity in an Arctic fjord (Adventfjorden, Spitsbergen). Polar Biology, 34, 833-845.

Pusceddu, A., Dell'Anno, A. \& Fabiano, M. 2000. Organic matter composition in coastal sediments at Terra Nova Bay (Ross Sea) during summer 1995. Polar Biology, 23, 288-293.

Quartino, M.L. \& De Zaixso, A.L.B. 2008. Summer macroalgal biomass in Potter Cove, South Shetland Islands, Antarctica: its production and flux to the ecosystem. Polar Biology, 31, 281-294.

Quartino, M.L., Deregibus, D., Campana, G.L., Latorre, G.E.J. \& Mомо, F.R. 2013. Evidence of macroalgal colonization on newly icefree areas following glacial retreat in Potter Cove (South Shetland Islands), Antarctica. PLoS ONE, 8, 10.1371/journal.pone.0058223.

Schloss, I.R., Ferreyra, G.A. \& Ruiz-Pino, D. 2002. Phytoplankton biomass in Antarctic shelf zones: a conceptual model based on Potter Cove, King George Island. Journal of Marine Systems, 36, 129-143.

De Skowronski, R.S.P. \& Corbisier, T.N. 2002. Meiofauna distribution in Martel Inlet, King George Island (Antarctica): sediment features versus food availability. Polar Biology, 25, 126-134.

Smith, C.R., DeMaster, D.J., Tomas, C., Sršen, P., Grange, L., Evrard, V. \& DeLeo, F. 2012. Pelagic-benthic coupling, food banks, and climate change on the West Antarctic Peninsula Shelf. Oceanography, 25, 188-201.

Steinarsdóttir, M.B., Ingólfsson, A. \& Ólafsson, E. 2003. Seasonality of harpacticoids (Crustacea, Copepoda) in a tidal pool in sub-arctic south-western Iceland. Hydrobiologia, 503, 211-221.

Thomas, D.N., FogG, G.E., Convey, P., Fritsen, C.H., Gilli, J.-M., Gradinger, R., Laybourne-Parry, J., Reid, K. \& Walton, D.W.H. 2008. The biology of polar regions. Oxford: Oxford University Press.

TietJen, J.H. 1969. The ecology of shallow water meiofauna in two New England estuaries. Oecologia (Berlin), 2, 251-291.

Tita, G., Desrosiers, G., Vincx, M. \& Clément, M. 2002. Intertidal meiofauna of the St Lawrence estuary (Quebec, Canada): diversity, biomass and feeding structure of nematode assemblages. Journal of the Marine Biological Association of the United Kingdom, 82, 779-791.

Vanhove, S., Beghyn, M., van Gansbeke, D., Bullough, L.W. \& VINCX, M. 2000. A seasonally varying biotope at Signy Island, Antarctic: implications for meiofaunal structure. Marine Ecology Progress Series, 202, 13-25.

VeIt-KöhleR, G. 2005. Influence of biotic and abiotic sediment factors on abundance and biomass of harpacticoid copepods in a shallow Antarctic bay. Scientia Marina, 69, 135-145.

Veit-Köhler, G., Antacli, J.C. \& Rose, A. 2008. Metazoan meiofauna in Potter Cove, King George Island. Berichte zur Polar- und Meeresforschung, 571, 135-140.

VINCX, M. 1996. Meiofauna in marine and freshwater sediments. In Hall, G.S., ed. Methods for the examination of organismal diversity in soils and sediments. Wallingford: CABI Publishing, 187-195.

Warwick, R.M., Platt, H.M. \& Somerfield, P.J. 1998. Free-living marine nematodes. Part III Monhysterids: pictorial key to world genera and notes for the identification of British species. Shrewsbury: Field Studies Council, $296 \mathrm{pp}$.

Wentworth, C.K. 1922. A scale of grade and class terms for clastic sediments. Journal of Geology, 30, 377-392.

WIESER, W. 1953. Die Beziehung zwischen Mundhöhlengestald, Ernährungsweise und Vorkommen bei freilebenden marinen Nematoden. Arkiv för Zoologi, 4, 439-484.

WIESER, W. 1960. Benthic studies in Buzzards Bay. II. The meiofauna. Limnology and Oceanography, 5, 121-137. 